\title{
1. Introduction to comparative law and anthropology
}

\author{
James A.R. Nafziger
}

\section{MUTUAL INSIGHTS AND OUTLOOKS ACROSS A PROFESSIONAL DIVIDE}

At the congested intersection of law and anthropology today, legal pluralism and anthropological eclecticism are prominent, perhaps even paramount. If, indeed, the roads from law lead plainly to anthropology, as the jurist Oliver Wendell Holmes, Jr. famously observed, ${ }^{1}$ there is significant traffic in both directions. The chapters in this book demonstrate the mutuality, though certainly not congruence, between the two disciplines.

By integrating insights from anthropology and kindred social sciences about social ordering as well as systems of knowledge and power within diverse cultural contexts, the concept of legal pluralism enriches our understanding of law and institutions, not only in a purely normative sense, but also in the actual practices of particular societies and the world at large. ${ }^{2}$ One can readily appreciate why, for over a half century, such "interdisciplinary study - the analysis of questions across the divide between disciplines - has come to dominate legal scholarship."3 Reciprocally, insights from the legal profession help shape the contours of social and cultural anthropology. Of course, the concept of legal pluralism, derived from empirical investigation and analysis across a disciplinary divide, must do more than simply alert us to the breadth, diversity and complexity of social controls. It must help reveal the issues and choices that the broadened field of analysis entails for individuals, communities, governing authorities

1 Oliver Wendell Holmes, Jr., Lecture, Harvard University (Feb. 17, 1886), in Notes, 20 AM. L. Rev. 742 (1886); see Leonard A. Jones, Oliver Wendell Holmes, the Jurist, 36 Am. L. REv. 710, 720 (1902). Justice Holmes later observed that "[i]t is perfectly proper to regard and study the law simply as a great anthropological document." Oliver Wendell Holmes, Law in Science and Science in Law? 12 HARV. L. REV. 443, 444 (1899).

2 See John Griffiths, What is Legal Pluralism? 24 J. Legal Pluralism I (1993) (comprehensively analyzing the concept); Isaak Dore \& Michael T. Carper, Multiculturalism, Pluralism, and Pragmatism: Political Gridlock or Philosophical Impasse? 10 WillameTte J. INT'L L. \& DISP. RESOL. 71 (2002) (discussing philosophical dimensions of the relationships between pluralism, traceable to its establishment as an epistemological category by William James, and multiculturalism). But see Brian Z. Tamanaha, Understanding Legal Pluralism: Past to Present, Local to Global, 29 Sydney L. REv. 36 (2007); Brian Z. Tamanaha, The Folly of the "Social Scientific" Concept of Legal Pluralism, 20 J.L. \& SoC'Y 192 (1993) (arguing that the concept of legal pluralism is constructed upon an unstable analytical foundation that will ultimately lead to its demise).

3 Robert B. Ahdieh, Notes from the Border: Writing Across the Administrative Law/ Financial Regulation Divide, 66 J. Legal EduCATION, No. 1, at 64 (2016). 


\section{Comparative law and anthropology}

and intergovernmental organizations. For example, if "the law," at least in nontotalitarian societies, can be seen as a flexible language that extends beyond authoritative rules to control deviant behavior, then its social impact may entail individual actions in pursuit of goals and strategies based on choices among alternative norms and institutions, that is, on purposeful exercises of agency. ${ }^{4}$

Legal anthropology (or the anthropology of law) $)^{5}$ necessarily engages the perspectives if not techniques of comparative law. Indeed, it has been suggested, somewhat startlingly, that anthropology as a whole is "something of a child of comparative law." 6 Whether one accepts this proposition or not, the relationship between the two disciplines has been nurturing. For example, comparative insights reinforce wellgrounded skepticism in the social sciences including anthropology about the dominance of formalism, positivism and statism in shaping and controlling social behavior. A related synergy involves the role of custom, in addition to formal governmental measures, as an expression at the grassroots of the normative order. Anthropological insights can be instrumental in helping define the relationship between law and custom, a question that has persisted from at least the time of Cicero. ${ }^{7}$ The law in books and law in action often diverge.

To be sure, the two disciplines often pursue different inquiries. Legal scholars and practitioners typically use comparative insights to help resolve discrete problems, to highlight contrasting aspects of their own legal system, and to provide alternatives for legal reforms and revisions. Anthropologists, on the other hand, seek to understand the origins and development of rules and procedures, how and why they persist institutionally or otherwise, and what consequences result. ${ }^{8}$ Anthropological insights can thereby help explain, for example, why European law has been more protective of cyber privacy and less tolerant of the marketing of genetically modified food sources than U.S. law.

4 Jane Fishburne Collier, Law and Social Change in Zinacantan 249 \& passim (1973). Collier argues that distinct and overlapping customary and formal institutions of the state, coupled with options within a repertoire of legal language, have enabled community members to make choices for individual ends, even involving deliberate violations of social norms to precipitate a crisis or defeat a rival. Indeed, in describing the fundamental relationship between legal decisions and social order, she observes that, "decisions may indeed reaffirm the basic tenets of social structure, but they also provide the basis for future 'deviant' acts. Legal decisions in quarrels provoked by such irresolvable conflicts do not provide individuals with clear models to direct their future behavior, but leave them trapped in intolerable situations where relief can only be obtained by breaking some 'law' that precipitates a crisis and a realignment of social relationships." Id. at 248. As another example, the globalization of critical domains of social activity has blurred the normative divide between the overlapping scopes of local and transnational authority, thereby once again offering alternative discourse and institutional access to persons faced with ordinary issues such as land ownership and tenure. See Anne Griffiths, Re-envisioning the Local: Spatiality, Land and Law in Botswana, 9 INT'L J.L. IN CONTEXT 213 (2013).

5 Hereinafter, the term "legal anthropology" will also refer to the "anthropology of law."

6 Martha Mundy \& Tobias Kelly, Introduction, in LAW AND ANTHROPOLOGY xv (Martha Mundy ed., 2002).

7 See, e.g., A. Arthur Schiller, Custom in Classical Roman Law, 24 VA. L. REV. 268, 270 (1938), reproduced in Alison Dundes Renteln \& Alan Dundes, I Folk LAW 33, 35 (1994).

8 See David Nelken, 61 InT'L \& CoMP. L. Q. 1017, 1019 (2012) (book review). 
The discipline of comparative law has developed almost entirely within a spatial or geographical framework involving the study of national and subnational legal systems within distinctive legal traditions. ${ }^{9}$ The historical divergence of these traditions from each other, and more recently their convergence with each other, have commanded the attention of both lawyers and anthropologists, particularly those focused on postcolonial societies and the influence of globalization. The geographical preoccupation of the discipline has been questioned, however. More expansive contours of comparative law have seemed advisable, primarily to include legal history and alternative legal philosophies or jurisprudential approaches within a single legal system. A few of the chapters in this book adopt this broader view of the discipline.

Legal anthropology has a long history with several notable benchmarks. ${ }^{10}$ Its origin is traceable at least as far back as the nineteenth-century jurist Carl Savigny's critical argument, during the protracted codification of German civil law, that culture and history should determine national law and legal institutions. Such convictions also inspired so-called armchair theories of cultural and legal evolution, often in the service of colonialism. But anthropologists soon abandoned the comfort of their armchairs. Beginning in the twentieth century, anthropological fieldwork developed, inspiring a better informed, more scientific interest in social ordering and control in different societies. Bronislaw Malinowski's insistence on the method of participant observation, including his own immersion in the Trobriand society or societies of Melanesia, established a durable model of empirical inquiry. Moreover, his specific conclusions, such as the role of reciprocity, ${ }^{11}$ contributed to a much broader understanding of law in society, liberated from the armchair constructs that had been formulated in Western legal systems.

The formalistic or legalistic focus on rules during the formative years of anthropology was displaced by a more subtle understanding of law as process or as language to mediate social knowledge and power. Also, the discipline gradually shed its colonialism-inspired agenda and earlier assumptions about an evolutionary modernization of legal systems. The profession gained new appreciation of and respect for the

9 By "traditions" (or "families"), comparativists refer to the broad classification of legal systems, primarily those based on the French and German civil codes and those based on the so-called common law. But other traditions include socialist, Islamic, indigenous, and mixed or hybrid systems. In a classic categorization, René David proposed three legal families: RomanoGermanic, common law and socialist law. RENÉ DAVID, TRAITÉ, ÉLÉMENTAIRE DE DROIT CIVIL COMPARÉ (1950).

10 For a succinct summary of this development, see Mark Goodale \& Elizabeth Mertz, Anthropology of Law, in 1 ENCYCLOPEDIA OF LAW \& SOCIETY 68 (David S. Clark ed., 2007).

11 It appears that Malinowski attached a double meaning to the term, as both an element in his definition of "law" and as a principle to govern inter-group conflict. As to the definitional context, it has been observed that "[r]eciprocity provides the phenomenological experience of law as a binding obligation that [Malinowski] believed separates law from mere custom." James M. Donovan, Reciprocity as a Species of Fairness: Completing Malinowski's Theory of Law, in BRONISLAW MALINOWSKI's CONCEPT OF LAW 83, 87 (Mateusz Stępién ed., 2016). On the other hand, Malinowski's understanding of reciprocity in an inter-group context removes the term from the definition of law (although "[i]t can be embodied in law or re-established by law." Tomáš Ledvinka, Bronislaw Malinowski and the Anthropology of Law, in Stępién ed., id. at 55, 68). 


\section{Comparative law and anthropology}

relative efficacy of traditional institutions. ${ }^{12}$ Eventually, anthropologists shifted some of their attention from pre-industrialized, economically developing societies to industrialized, economically developed societies. Human rights, ${ }^{13}$ globalization and transnational norms came into view, as did activist agendas and strategies on behalf of members of indigenous and other minority groups. Today, the still controversial practice of advocacy scholarship is arguably all but unavoidable in, for example, the anthropological study of human rights, governmental corruption, terrorism, and the scourge of violence and armed conflict.

\section{LEGAL PLURALISM AND DISPUTE RESOLUTION}

Within the ambit of legal pluralism, a central theme for analysis has been dispute resolution and process. The renowned collaboration between an anthropologist, E. Adamson Hoebel, and a legal realist, Karl Llewellyn, produced The Cheyenne Way, ${ }^{14}$ which focused on "trouble cases" as guidance toward a deeper understanding of an indigenous culture and way of life. Later, Clifford Geertz, Leopold Pospisil and others integrated this simple, reflective variation of the legal case method into broader inquiries into the structure of societies.

\section{A. Macroanalysis ${ }^{15}$}

Pospisil's pathfinding Ethnology of the Law ${ }^{16}$ articulated a growing professional skepticism about legalism as a reliable concept for cross-cultural analysis. In Pospisil's view, legalism is essentially "the 'folk conceptualization' of law by Europeans." 17 His preference for a reliance on principles abstracted from legal decisions led to his identification of four attributes of law: authority, intention of universal application, obligatio (roughly, the rights and duties of parties to a legal relationship) and sanction. Turning to the myriad methods of settling disputes, he argued that they are not differentiated by degrees of formality, as we might generally assume, but rather with "the locus of solution-production activity and power of persuasion."18

12 See, e.g., Kate Baldwin, The Paradox of Traditional ChiEFs in Democratic Africa (2015) (noting, somewhat paradoxically, the increasing strength of unelected chiefs as effective "development brokers" in assisting elected politicians and otherwise lobbying them for improved social services and infrastructures).

13 For example, a recent study of evicted tenants, oriented to their civil and human rights, involved the immersion of the author, an anthropologist, within a low-income community of Milwaukee. Matthew Desmond, Evicted: Poverty and Profit in the American City (2016).

14 Karl N. Llewellyn \& E. Adamson Hoebel, The Cheyenne Way (1941).

15 Portions of this section are drawn from James A.R. Nafziger, Comparative Dispute Resolution: A New Look, 10 WiLlametTe J. INT'L L. \& DisP. ReS. 11 (2002).

16 LeOpold Pospisil, The ETHNOLOGY OF LAW (2d ed. 1978).

17 Id. at 18.

18 Id. at 33 . 
In arguing for a pluralistic approach to the phenomenon of law, Pospisil cited studies by Laura Nader, ${ }^{19}$ a contributor to this book and a pioneer in identifying different levels of law within a society. He was particularly interested in her observations about the relationships between distribution of adjudication and patterns of authority. Her studies, based on Mexican Zapotec culture, also revealed interesting connections among three variables: types of conflict, methods of resolving it and characteristics of disputing parties. Processes of control and modes of discourse (legal language) had largely replaced black-letter rules in the emerging discipline of legal anthropology. Even Hoebel and Llewellyn, focused as they were on trouble cases, acknowledged that "law-men" and "law ways" breathe life into the jurisprudence (Llewellyn, after all, was a legal realist).

On a macro level of analysis, the discipline of comparative dispute resolution mirrors comparative law as a whole. Their common functions include insights into characteristics of one's own system; thick descriptions of the various ways in which identical or similar rules are applied in different legal systems; possibilities of legal reform by transplantation of rules, principles and processes; and data for defining international custom and for distilling general principles of international law. Comparative dispute resolution may be especially helpful in revealing significant characteristics of a culture. For example, in traditional Chinese dispute resolution the essential relationship between " $l i$ " (propriety or social expectations) and " $f a$ " (positive, enforceable law), with all of their variations in modern society, ${ }^{20}$ speaks volumes about Chinese culture.

An understanding of the role of dispute resolution in other cultures can be consequential. For example, Thomas Kiefer's study of Muslim Tausug culture in the Philippines $^{21}$ provided significant insights into both traditional methods of dispute resolution and popular perceptions of "government" court systems. Kiefer found that conflicts, including those resulting in acts of homicide, ${ }^{22}$ were generally "settled out of court by traditional means." Counterintuitively, the highly pragmatic Tausugs often pursue litigation in order to further a dispute rather than settle it. Kiefer concluded that "[t]he crux of the entire problem of the relationship between rural Tausug and the Philippine government lies in the conflict of legal institutions." He emphasized the critical need for dialogue and institutional accommodation in resolving disputes and thereby keeping the peace. By contrast, he found that relations between the Tausug and military authority (the constabulary) and the need for economic development were of less importance. ${ }^{23}$ Looking back on Kiefer's observations concerning conflict between governmental and traditional institutions, one has cause to be wistful. What if his insights had been taken more seriously by those in a position to influence the

19 See, e.g., Laura Nader, An Analysis of Zapotec Cases, 3 Ethnology 404 (1964); Laura Nader \& Duane Metzger, Conflict Resolution in Two Mexican Communities, 65 AM. ANTHROPOLOGIST 584 (1963) (cited in Pospisil, supra note 16, at 26).

20 See, e.g., James A.R. Nafziger \& Ruan Jiafang, Chinese Methods of Resolving International Trade, Investment, and Maritime Disputes, 23 Willamette L. ReV. 619, 621-24, 676-77 (1987).

21 Thomas M. Kiefer, The Tausug: Violence and Law in a Philippine Moslem Society (1972).

22 Id. at 139.

23 Id. at 138. 
Philippine government? Rather than falling on deaf ears, perhaps those insights might have helped avert at least some of the inter-religious conflict and terrorism that subsequently have plagued that country.

A focus on processes of dispute resolution, sharpened by comparative analysis, can also deepen our understanding of alternative modes of governance through history. Until recently, for example, the Icelandic Althing, dating back to the tenth century A.D., was viewed as the world's oldest continuous parliament, "the mother of all known parliaments." ${ }^{24}$ On closer look, however, the annual assembly at Thingvellir ${ }^{25}$ appears to have been less like a modern legislative body, or even a judiciary, than a sort of multi-door courthouse for resolving disputes by negotiation or arbitration. In resolving the kinds of quarrels and feuds that animate Icelandic sagas, for example, what really mattered was the ability of authoritative chieftains and, later, bishops, forming coalitions of power, to negotiate and arbitrate disputes brought to them. The sagas suggest that these processes of dispute resolution typically involved exchanges of goods and services, often leading to the settlement of debts. ${ }^{26}$

In the absence of either central executive or effective judicial authority, the most important element in medieval Icelandic governance may have been a variable process of dispute resolution tailored to particular disputes. Once it is accepted that a process of dispute resolution formed the core of Icelandic governance, we can better understand the role of the traditional Icelandic law book called the Grágás ("gray goose") as a source of guidance rather than black-letter mandates. Similarly, it now seems that traditional decisions of the Lögrétta ("law council") were not mandatory, as had earlier been assumed. Instead, they could be accepted or rejected by the populace. ${ }^{27}$ There is also substantial evidence in the Icelandic sagas that ritualized exchanges of goods and services were more a matter of dispute resolution and maintenance of honor in festive halls and forums such as the Althing than simply the routine activity of a marketplace. "[W]hether the exchange was to be by feud or feast was what they bargained over."28 This reinterpretation of the Icelandic Althing is the product of both extensive research, freed of the romanticized premises and pretenses of nationalism and the blinders of modern governing structures and legal formalism, as well as a keen appreciation of the essentiality of dispute resolution in social organization.

One frontier of fieldwork focused on comparative dispute resolution involves the selection of appropriate and effective venues, as between state and customary courts or

24 See, e.g., Helgi Thorláksson, The Icelandic Commonwealth Period: Building a New Society, in Vikings: The North ATLAnTiC Saga 175, 175 (William W. Fitzhugh \& Elisabeth I. Ward eds., 2000) (reviewing the historical understanding of the Althing at the time of the 1,000-year anniversary of the Althing in 1930) [hereinafter VIKINGS]. See also Anne-Sofie Gräslund, Religion, Art, and Runes, in VIKINGS, at 55, 61.

25 For a vivid depiction of the assembly in the year A.D.1000, when the "law speaker" announced Christian governance, see Peter Schledermann, A.D. 1000: East Meets West, in VIKINGS, id. at 189.

26 See William Ian Miller, Buying and Plundering: Exchange in Medieval Iceland, 31 L. QUADRANGLE NOTES, Fall 1986, at 34-8 (citing passages from the Eyrbyggja saga and Njal's saga).

27 Thorláksson, in VIKINGS, supra note 24, at 176-83.

28 Miller, supra note 26, at 40. 
a combination of them. Anthropological insights into such questions are essential. ${ }^{29}$ Another frontier of dispute resolution involves societies in a state of anomie in which normative standards appear from the outside to be weak and mob justice prevails. Accordingly, homicide within a group as well as war against neighboring peoples and their demonization may lie beyond the competence of formal law enforcement. Revenge killings, for example, remain ritualized and subject to often contrasting rules of decorum between contending groups. For example, organized public battles to resolve issues involving the Dani clan in the New Guinea Highlands are confined by their rules to daytime and suspended by rainfall, whereas their frequent adversaries of the Nipa clan do not observe such rules. ${ }^{30}$ Overarching rules are clearly needed. More dangerous private fights, often involving ambushes by stealth killers, obey their own set of rules that may, for example, allow destruction, but not by incineration, of an enemy's hut. ${ }^{31}$ Throughout the world and in diverse societies, including those of the Western developed world, mob justice does, indeed, offer a form of dispute resolution that provides both emotional release and some measure of social stability, but nevertheless merits displacement by less dangerous practices and more suitable institutions of social control. ${ }^{32}$

\section{B. Microanalysis}

On a micro level of analysis, it is apparent that the use of anthropological evidence in specific instances of dispute resolution such as trials contributes not only to the legal process itself, but also to the satisfaction of cultural and social values underlying the evidence and its acceptability. A few examples may help make that point.

29 The literature on this set of issues or dilemmas is vast. For a recent example, see Janine Ubink, Access vs. Justice: Customary Courts and Political Abuse - Lessons from Malawi's Local Courts Act, 64 AM. J. CoMP. LAW 745, 753-54 (2016), observing more generally as follows (citations omitted):

In many countries, governments have tried to curtail the power of traditional leaders and the reach of customary law and to replace parts of the customary justice system with statutory law, but such attempts have been incomplete and the mere abolition of customary ... law by the state does not necessarily mean that these laws [are] no longer used by the population, although their social force may be affected. Recent decades have witnessed a resurgence of traditional leadership and a reevaluation of customary justice systems, the latter closely connected to the recognition of cultural and group rights. Also, among rule-of-law practitioners, the realization of the limited impact of attempts to increase access to state courts for the poor combined with a recognition of the continued relevance of customary law for the regulation of the daily lives of the majority of Africa's citizens, led to renewed interest in the operation of customary justice systems. The question was how to maintain the accessibility of customary justice systems while enhancing the quality of their provision of justice.

30 See Jared Diamond, Vengeance is Ours, New Yorker, April 21, 2008, at 74, 79.

31 Id.

32 For an example of "bringing justice" (by a floating courtroom) to an anarchical region of mixed indigenous people and settlers ruled by mob justice, see Simon Romero, A Floating Courthouse Takes Rule of Law to Brazil's Frontier, N.Y. Times, December 7, 2016, at A4 (noting that "all too often, the jungle's residents still reach for machetes to settle feuds"). 
In Delgamuukw v. British Columbia ${ }^{33}$ the Gitksan and Wet'suwet'en Nations claimed ownership and jurisdiction rights over some 133 individual hereditary territories comprising 58,000 square kilometers of British Columbia. ${ }^{34}$ The Crown of British Columbia argued, however, that the nineteenth-century colonial government had extinguished all First Nation land rights. The trial court agreed, holding that aboriginal rights generally existed but could be extinguished at the pleasure of the Crown. The claims therefore failed as existing rights under subsection 35(1) of Canada's 1982 Constitution. The Court of Appeal upheld the decision after the substitution of aboriginal title and self-government for the original claims of ownership and jurisdiction. The Supreme Court of Canada ruled, however, that aboriginal sovereignty prevailed over the Crown's prerogatives under both statutory and common law. The Court, noting a governmental duty to consult with First Nations and if possible accommodate their interests based on aboriginal title, ${ }^{35}$ remanded the case to the trial court for a decision to be based on a determination of the scope of aboriginal title and the claims under it. The Court concluded with a pithy observation about the practicality of a just resolution of the dispute: "Let us face it, we are all here to stay."36

Of greatest interest was the Canadian Supreme Court's treatment of oral history as primary evidence to support the aboriginal claims. The Court first ruled that the trial judge's refusal to accept the expert testimony of two anthropologists, though "hotly contested," would stand insofar as findings of credibility were beyond its powers of review. ${ }^{37}$ Nevertheless, the Court, supported by anthropological evidence and its own jurisprudence, ruled that the oral histories of the Gitksan and Wet'suwet'en nations, based in part on ceremonial songs, did indeed have independent weight. The Court thereby overruled the trial judge's rejection of the proffered oral histories because they did not accurately convey historical truth, because knowledge about them was confined to the communities to which the histories pertained, and because they were insufficiently detailed. If these assertions were determinative, the Court ruled, the Canadian legal system would consistently and systematically undervalue oral histories contrary to prior jurisprudence. ${ }^{38}$ As a matter of comparative dispute resolution, the Court's respect for oral history was in line with that of other legal systems as reflected, for example, in the Native American Graves Protection and Repatriation Act (NAGPRA) of the United States. ${ }^{39}$

33 (1997) 3 S.C.R. 1010 (Can.) [hereinafter Delgamuukw]. For commentary, see Elizabeth Cassell, Anthropologists in the Canadian Courts, in LAW AND ANTHROPOLOGY 187, 188 (Michael Freeman \& David Napier eds., 2009).

34 For an in-depth account of the dispute and its background, see TERRY GLAVIN, A DEATH FEAST IN Dimlahamid (1990).

35 Delgamuukw, supra note 33 II 168.

36 Id. \I 186.

37 Id. II 91.

38 Id. II 98.

3925 U.S.C. $\$ \S 3001-13$ (2012). 
A second case highlights a more direct, crucial use of expert testimony by anthropologists to support a "cultural defense" 40 by criminal defendants, according to which a customary practice may exonerate them from prosecution. The California Supreme Court's decision in People v. Woody ${ }^{41}$ was seminal in what became a line of jurisprudence based on religious freedom regarding the so-called federal peyote exemption from the regulation of controlled substances. Accordingly, the use of the cactus buttons known as peyote, whose principal constituent is the hallucinogenic agent mescaline, as both a sacrament and an object of worship by established Native American churches, is protected as a matter of religious freedom under the First Amendment of the United States Constitution. In its seminal decision in Woody, the California Supreme Court ruled that the Native American defendants were entitled to the exemption and thereby not subject to prosecution for the illegal possession of narcotics.

The Court's decision relied on the expert testimony of anthropologists, based on their conversations with members of the Native American Church of California, ${ }^{42}$ that peyote is a fundamental element in their religious practice, that the practice had become well-established during the latter part of the nineteenth century, that it had become uniformly ritualized, that it was both a sacrament and an object of worship, that it was the sine quo non of the defendant's faith, ${ }^{43}$ and that it is a positive rather than negative force in the lives of its adherents. ${ }^{44}$

A last example of microanalysis engaging comparative dispute resolution, this time at the international level of litigation, is the European Court of Human Rights decision in Hingitaq 53 v. Denmark. ${ }^{45}$ It made extensive use of ethnographical evidence ${ }^{46}$ to uphold the amount of compensation that the Danish government had granted the Thule Tribe of Inuits in Greenland after the tribe's forced relocation and restriction of access to traditional hunting and fishing to make way for a foreign (United States) anti-aircraft installation. This decision of a regional human rights tribunal offers a reminder of both the appreciation of pluralism and the eclecticism that characterize anthropology - and specifically legal anthropology - today.

\section{ANTHROPOLOGICAL ECLECTICISM}

The expansive scope of the chapters in this book reveals the eclecticism that characterizes anthropological research today as it interacts with law. First, there is no longer some kind of a Holy Grail or uniform paradigm for research, nor any longer a

40 See Alison Dundes Renteln, The Cultural Defense (2003); Alison Dundes Renteln, Cross-Cultural Dispute Resolution: The Consequences of Conflicting Interpretation of Norms, 10 Willamette J. InT'L L. \& Disp. Res. 103 (2002).

$41 \quad 61$ Cal. 2d 716, 394, P.2d 813 (1964).

42394 P. 2nd at 817.

$43 \quad 394$ P. 2nd at 820 .

44394 P. 2nd 815, n.3.

45 Eur. Ct. H.R. App. No. 18584/04 (2006).

46 Id. at 20. 
unified object of study or field of research such as non-state or non-Western societies. ${ }^{47}$ Indeed, as reflected in Hingataq 53, the geographical horizons now encompass international institutions and rules of law. Cultural insights can inform the application of not only human rights and other public international law, but also private international law (conflict of laws). ${ }^{48}$ Investigations of non-state practices range from the fashion industry to semi-institutionalized labor practices to data privacy and other issues in cyberspace. Second, there is no single analytic focus such as dispute resolution, let alone more specific aspects of it such as Hoebel and Llewellyn's trouble cases. At the still relatively unexplored level of governance by states, the open targets for research include political behavior, legislation, administration, regulatory institutions, educational environments and other facilitative functions of law and legal institutions. Third, historians, economists, environmental management experts and other social scientists all contribute to the advancement of legal anthropology. ${ }^{49}$ The need for expertise extends even beyond social science. For example, the possible hard-wiring of humans for war, peace-making or other concerns of both law and anthropology merits recourse to expertise in the "hard" sciences. ${ }^{50}$ Fourth, the cultural, not to mention activist, focus of legal anthropology has merged with a cultural heritage focus of both archeology and cultural law $^{51}$ as that heritage has become better appreciated as well as increasingly imperiled. Finally, anthropological eclecticism has

47 See Mundy \& Kelly, supra note 6, at xviii-xix. The authors identified three characteristics of legal anthropology: "A continuing commitment to ethnographic description that privileges process and act over doctrine; a critical view of the categories of law marked by a long disciplinary history of grappling with ethnocentrism; and concern with culture, however defined, and hence with situating legal culture in society." Id.

48 This is nothing new. For example, Bronislaw Malinowski "detected the Trobriand equivalent of private international law." Ledvinka, supra note 11, at 71 . For a more recent discussion of the role of private international law, informed by anthropological insights, see Annelise Riles, Cultural Conflicts, in Freeman \& Napier, supra note 33, at 89. Generally, statutory or judicial provisions for taking into account or applying law of indigenous groups largely accomplish this aspiration. For example, in the State of Oregon's codification of choice of law for contracts, torts and other non-contractual claims, for which I served as a Reporter, the first two provisions supply definitions of "Law" and "State," which together confirm the applicability of Indian tribal law and Native Hawaiian law (essentially customary) in the choice-of-law process. ORS $\S \S 15.300,15.305$ (2015). Also, in instances of a conflict of laws, the General Rule for application of the "most appropriate law" in contract cases is determined by, inter alia, "giving effect to justified expectations of the parties concerning which state's law applies to the issue." ORS $\$ 15.360$ (2015).

49 Freeman \& Napier, supra note 33, at 17 (noting that "[t]he developments in our field have to a large extent run parallel with, and have been influenced and enriched by developments in social anthropology and other social sciences (history, sociology, legal science, political science, psychology). In recent times there has also been an increasing trend towards a geography of laws" [citations omitted]).

50 See, e.g., David P. Barash, Are we Hard-Wired for War? N.Y. TimES, Sept. 29, 2013 (citing several examples of peacemaking proclivities of societies in Tanzania, New Zealand and Malaysia).

51 For materials and commentary on this comprehensive discipline see CULTURAL LAW: International, Comparative, And Indigenous (James A.R. Nafziger, Robert Kirkwood Paterson \& Alison Dundes Renteln eds., 2010). 
offered insights into fundamental legal principles and norms such as those of human rights and constitutional law. These insights can lead to surprising theories and conclusions about the origins of what we ordinarily regard as "modern" law. For example, an anthropologist argued that the separation of church and state and concomitant freedom of religion could be reasonably traced to the tolerant policy under the Mongol rule of Genghis Khan as his empire expanded from Asia to Europe. ${ }^{52}$

Although several identity markers are apparent, ${ }^{53}$ it is obvious that legal anthropology has pushed well beyond the clearly defined contours to which it was traditionally confined. The sheer indeterminacy of the law and the ambitions of anthropological research have both helped confirm that the relationships between comparative law and culture, comparative law and custom - and indeed to return to an earlier point, ${ }^{54}$ comparative law and anthropology as a whole - are better described in pragmatic and utilitarian rather than definitive semantic terms. Thus, for example, the discipline of legal anthropology can enlist the envelope-pushing work on custom of both anthropologists and lawyers even though they may view its materiality differently. ${ }^{55}$ What then, are the disciplinary boundaries or identities of legal anthropology today? It has been said that "[ $\mathrm{t}]$ he lawyer and the sociologist [read anthropologist] may be neighboring landowners; they may even be able to cooperate to use their lands for the benefit of the community; but they are not joint tenants." 56

Despite the dissimilarities, the two generic disciplines of anthropology and law "are alike absorbed with the artisan task of seeing broad principles in parochial facts." 57 In

52 JaCk WeATHERford, Genghis KHAN AND THE QUEST FOR GOD: How THE WORLD'S Greatest CONQueror GaVe us Religious FreEdom (2016).

53 See Franz von Benda-Beckmann, Riding or Killing the Centaur? Reflections on the Identities of Legal Anthropology, in Freeman \& Napier, supra note 33, at 13, 15.

$54 \quad$ See text at supra note 7.

55 See A.N. Allott, Methods of Legal Research into Customary Law, 5 J. AFRICAN ADMIN. 172 (1953), reproduced in Renteln \& Dundes, supra note 7, at 285, 286, as follows:

Although anthropologists and lawyers investigating customary law may make use of the same material, they do so with very different aims. The aim of anthropology is wide, to record custom as one of the various phenomena of social life in the tribe or people under investigation. The anthropologist seeks to show the social purpose of customary rules, and how they fit into the structure of behavior. The aim of legal research is narrow, to record those rules of custom or usage which are either enforced in the courts, or are of a kind which the courts would enforce. Appreciation of the part which these rules play in the social structure is therefore irrelevant, or at most only needed as background-knowledge, or for the better elucidation of the meaning of these rules. It is fundamental that a clear distinction should be made where possible between rules having legal force, and those lacking the force of law, being backed merely by a social or moral sanction.

This raises the difficult problem of the binding character of customary law, a problem which need not worry the anthropologist.

56 Gordon R. Woodman, Some Realism About Customary Law - The West African Experience, 1969 WIS. L. REV. 128, 152, reproduced in Renteln \& Dundes, supra note 7, at 83, 104.

57 Clifford Geertz, Local Knowledge: Fact and Law in Comparative Perspective, in Clifford Geertz, LOCAL KNOWLEDGE: FuRTHER ESSAYS IN INTERPRETING ANTHROPOLOGY 167-68 (1983), quoted in Carol J. Greenhouse, Law and Anthropology: Old Relations, New Relativities, in Freeman \& Napier, supra note 33, at 47, 51. 
this light, the phrase "anthropology of law" as an alternative to "legal anthropology" seems especially appropriate. So does the observation that "[i]n its normal functioning, a discipline [referring to legal anthropology] does not actually need consensus on core assumptions. Rather like a hegemonic alliance, in Gramscian perspective, it requires consent, some overlapping interests, and a spirit of live-and-let-live across the differences." 58

Still, some management of the investigative environment and some disciplinary constraints are in order. Franz von Benda-Beckman has concluded that although there are hardly any exclusive identity markers to define the boundaries of legal anthropology (or the anthropology of law), it is an accumulation of seven features that matters. These features, which have been adopted to form the organizational structure of this book, are as follows: its specific attention to complexity and legal pluralism, the totality of legal ideas normatively oriented at and/or involved by actors; its attention to the substance of legal schemes of meaning and to the social significance of law (plural legal elements) in social life; its more cosmopolitan comparative perspective, within and between cultures/societies/states; its historical orientation; its sensitivity to contextual differences; its reliance largely on in-depth field research as a major way of getting "quality data"; and the relation of its work to the legal anthropological tradition and its older and newer theoretical and methodological concerns. ${ }^{59}$

Of course, none of the chapters in this book are a perfect fit within this framework. They were not written with the framework in mind. Moreover, each one of the chapters substantially transcends the particular feature of legal anthropology to which it has been assigned. The classification of each chapter is therefore somewhat arbitrary. After all, it is an accumulation of features that defines the discipline. Matching each of the multi-faceted chapters with a single feature is itself a comparative exercise in weighing the respective contributions of a particular chapter vis-à-vis other chapters - much like the operation of comparative advantage in classical economics. Finally, questions may be raised about the definitional/organizational framework itself. It is not the last word, but rather a plausible set of features that offers a convenient way of organizing the chapters in this book.

The authors of the following chapters represent a broad range of disciplines, expertise, nationalities and experiences in a wide variety of legal systems. They were encouraged on a generally open-ended basis to choose their topics and scientific approaches. The chapters therefore blend the expertise of long-established, acclaimed scholars of legal anthropology with new voices from a range of disciplines and backgrounds. Taken together, the book extends a long-developing trend in legal anthropological research from the study of externally imposed to internally generated interpretations of norms and processes of legal significance within particular cultures and social orders. The book also adopts an expansive conceptualization of comparative law that encompasses not only its traditional geographical orientation but also historical and jurisprudential dimensions.

58 James Clifford, Rearticulating Anthropology, in UNWRAPPING THE SACRED BUNDLE: Reflections on the Disciplining of ANTHROPOlOGY 27 (D.A. Segal \& S.J. Yanagisako eds., 2005).

59 Von Benda-Beckmann, supra note 53, at 36. 
We begin the exploration of these dimensions of the discipline with the succinct contributions, in alphabetical order of their surnames, of two of the most eminent pioneers of legal anthropology today, Sally Falk Moore and Laura Nader. 
James A. R. Nafziger - 9781781955185 Downloaded from PubFactory at 04/26/2023 10:38:31AM via free access 